\title{
Comparative Score -2
}

National Cancer Institute

\section{Source}

National Cancer Institute. Comparative Score-2. NCI Thesaurus. Code C126683.

A score of -2 on a comparative scale that ranges from 3+: Very much better to -3: Very much worse. 